\title{
FIBROUS LESIONS OF THE GINGIVA - A HISTOPATHOLOGIC ANALYSIS OF 204 CASES
}

Article type: Article.

Abstract:

Two hundred four cases of fibrous lesions of the gingiva were studied histologically for the presence of calcified tissue, the nature of the connective tissue, the type of keratinization, and the degree of epithelial thickness. Initially these lesions were subcategorized into four specific entities, namely fibrous epulis, fibroepithelial polyp, calcifying fibroblastic granuloma, and ossifying fibrous epulis. It was found that $46.5 \%$ of the lesions contained calcifications. The connective tissue was represented predominantly by either the collagenous type $(50.5 \%)$ or the mixed (cellular and collagenous) type (44.6\%). It was also found that $36 \%$ of the lesions were ulcerated, and, of these, $79.5 \%$ were associated with the cellular type of connective tissue and calcifications. In an attempt to subcategorize the fibrous lesions into specific entities, it was found that 32 cases (15.7\%) had mixed features. This fact supports the suggestion that these lesions are stages in the spectrum of a single disease process and should collectively be termed fibroblastic gingival lesions. However, it is also suggested that the two terms, namely peripheral fibroma and fibrous epulis with and without ossification, should be retained whereas the usage of other terminologies should be avoided.

\begin{tabular}{|c|l|}
\hline Author & Zain, R. B. ; Fei, Y. J. \\
\hline Source & $\begin{array}{l}\text { Oral Surgery Oral Medicine Oral Pathology Oral Radiology and } \\
\text { Endodontics }\end{array}$ \\
\hline ISSN & $1079-2104$ \\
\hline DOI & $10.1016 / 0030-4220(90) 90212-b$ \\
\hline Volume & 70 \\
\hline Page & $466-470$ \\
\hline Year & 1990 \\
\hline
\end{tabular}

Please Cite As:

ZAIN, R. B. \& FEI, Y. J. 1990. Fibrous lesions of the gingiva: A histopathologic analysis of 204 cases. Oral Surgery Oral Medicine and Oral Pathology, 70, 466470. 
URL:

- http://apps.webofknowledge.com $>$ Search Web of Science Accession No:A1990EC68300015

- http://www.sciencedirect.com/science/article/pii/003042209090212B

- http://www.scopus.com/inward/record.url?eid=2-s2.00025084570\&partnerlD=40\&md5=a49312ca265d09bcbfcceb72475276a1

- http://www.ncbi.nlm.nih.gov/pubmed/2120653 